\title{
Factors associated with perceived quality of life in artisanal fishermen: a cross-sectional study
}

\author{
Bhárbara Karolline Rodrigues Silva ${ }^{1 *} \mathbb{D}$, Francisco Winter dos Santos Figueiredo ${ }^{1}$, Erika da Silva Maciel ${ }^{2}$, \\ Fernando Rodrigues Peixoto Quaresma ${ }^{1,3}$ and Fernando Adami ${ }^{1}$
}

\begin{abstract}
Objective: To analyze a combination of socioeconomic and demographic characteristics, chronotype, stress perception and level of physical activity with the perception of quality of life in artisanal fishermen.

Results: Several variables were associated with lower scores of quality of life domains: workload $(P=0.047)$, age $(P=0.01)$, economic class $D-E(P=0.04)$ and perceived stress scores $(P=0.01)$ for scores physical domain; workload $(P=0.03)$ and perceived stress $(P<0.001)$ for scores psychological domain; Perceived stress $(P<0.001)$ and age $(P=0.01)$ for social domain scores; economic class $D-E(P=0.03)$ and perceived stress $(P=0.01)$ for environment domain scores; perceived stress $(P=0.01)$ and age $(P=0.01)$ for general quality of life scores and; female sex $(P=0.04)$ and age $(P=0.02)$ for the score of satisfaction with quality of life.
\end{abstract}

Keywords: Artisanal fishermen, Vulnerable populations, Quality of life, Chronobiology, Stress

\section{Introduction}

Worldwide there were more than 43.5 million fishermen in 2009 [1]. In Brazil, there were more than 970 thousand fishermen in 2014, of which approximately 957 thousand were artisanal fishermen [2], characterized by fishing autonomously, preserving socio-cultural traditions, with family regime, as a source of income, through their own production or in partnership, in small vessels with little autonomy $[3,4]$. This type of activity has great socioeconomic importance for several countries such as China, India, Indonesia, Japan and Chile $[5,6]$, as it represents employment and food security [3, 6-9].

They commonly work in precarious labor environments, with increased workloads and exposure to factors that compromise health, such as stress, insufficient physical activity, and shifts when biological predisposition (chronotype) is not respected. Chronotype can influence sleep quality, labor productivity, social performance and

\footnotetext{
*Correspondence: bharbarakarolline@gmail.com

${ }^{1}$ Epidemiology and Data Analysis Laboratory, Faculdade de Medicina do ABC (FMABC), Santo André, SP, Brazil

Full list of author information is available at the end of the article
}

disease development, such as cardiovascular and metabolic responses that are detrimental [10-17].

Socioeconomic and demographic vulnerabilities due to individual and/or collective issues, as unavailability to access resources, health services, potable water, sanitary sewage are factors which can increase susceptibility to diseases and impact on quality of life (QOL) [14, 16-19].

However, few studies analyze the perception of the quality of life and associated factors in vulnerable populations. Public policies to improve the health and right of the minority communities' need of the scientific evidences to improve it, but scientific evidences about this are gaps in the actual literature $[20,21]$. This situation makes artisanal fishermen less aware of their QOL when compared to the general population $[14,16]$.

In this sense, what factors can interfere in the diminished of the perception of the QOL of artisanal fishermen? The objective of this study was to analyze the association between socioeconomic and demographic characteristics, chronotype, stress perception and level of physical activity with the QOL perception in artisanal fishermen. 


\section{Main text Methods}

Cross-sectional study reported according to Strengthening the Reporting of Observational Studies in Epidemiology (STROBE) [22]. Performed in the state of Tocantins, north of Brazil, between 2016 and 2017.

In the Tocantins state (north of Brasil), there are 36 fishermen colonies registered in the Institute of Rural Development of the State of Tocantins (RURALTINS). Among these, the colonies "Itaobi", "Z-10", "Parque Sucupira " and "Colônia de Pescadores de Miracema do Tocantins (COPEMITO)" were selected for this study. The selected colonies are located around the watershed of the Tocantins River, second largest river in Brazil with $172,828 \mathrm{~km}^{2}$ and with great significance for the state economy for allowing besides fishing, aquaculture practice and tourism activities [23, 24].

The project was approved by the Committee of Ethics in Research with Human Subjects (no 50419215.5.0000.5516). Access to the colonies was obtained by means of a partnership with the Brazilian Company of Agricultural Research-Fishermen and Aquaculture (EMBRAPA). The collections were performed by previously trained staff, through face-to-face interviews.

Were evaluated for eligibility all artisanal fishermen registered in the selected colonies $(n=175)$, with 18 years or more. Those who refused to sign an informed consent form $(n=20)$ or withdraw consent during the data collection phase $(\mathrm{n}=10)$ were not included. In total, 145 artisanal fishermen composed the sample, and 01 were excluded due to inadequate data filling.

The socioeconomic and demographic characteristics were obtained by data collection form prepared by the authors. The Economic Classification was evaluated through the Questionnaire of the Brazilian Association of Research Companies (ABEP). The Economic Classification was evaluated through the Questionnaire of the Brazilian Association of Research Companies (ABEP). Composed of 15 questions, which assess the quantity of automobiles, bathrooms, appliances, electronics, employees, educational level, origin of water used in the home and whether the stretch of the street that resides is paved. The socioeconomic level was classified according to the Brazilian Economic Classification Criteria (Classes A, B, $\mathrm{C}$, and $\mathrm{D}-\mathrm{E}$ ) that represents the socioeconomic strata of the population (e.g. class A has better education, income, life conditions while Class D-E has poorest education, income, as well other socioeconomic indexes assessed by the questions) [25].

Perceived stress, measured by the EPS-10 Stress Perceptual Scale considered as a global stress measure, validated for the Brazilian population [26, 27]. This instrument assesses the perception of stress in certain situations within the last 30 days, and is related to a series of self reports and behavioral criteria. The instrument is composed of 10 items evaluated on a Likert scale, and the final result corresponds to a score from 0 to 40 . The higher the final score the greater the perceived stress [27].

To evaluate the chronotype of the participants, the Morning and Evening Individual Identification Instrument $[26,28]$ was used, which classifies them in the Morning, Moderately Morning, Intermediate, Evening and moderately evening, according to the individual's preferred daily habits $[29,30]$. Individuals classified as morning have a greater predisposition to sleep and wake up early, with better work performance and alert level in the morning; those classified as intermediaries have better flexibility, can adapt to schedules according to needs, and evening individuals have a preference for sleeping and waking up late, with better performance in the afternoon and early evening [26, 31, 32].

Physical Activity Level was evaluated by the International Physical Activity Questionnaire (IPAQ) version 8, short form and normal week. The participants were classified as having low, moderate or high level of physical activity $[33,34]$.

The QOL perception was evaluated through the WHOQOL-bref instrument (World Health Organization Quality of Life), developed and validated by the World Health Organization (WHO), composed of 26 facets. The facets are divided into 4 domains of quality of life, which are physical, psychological, social relations and environment. Self-perception is assessed through the mean scores of the domains and the higher the score, the better the QOL perception [35-37].

The QOL perception and perceived stress are selfreported and subjective measures that can be influenced by psychological phenomena, discernment of the values they are inserted and by personal judgment itself [37, 38]. This subjectivity and possibility of influence by external factors can generate information bias. Measures such as the training of interviewers and the use of validated instruments for the Brazilian population were carried out to reduce this bias.

Due to the lack of studies on the QOL of artisanal fishermen, the QOL parameter of a study with a resident population in one of the study cities (Palmas-TO) was used to estimate the sample size calculation, having as parameter the greatest variability found of the indicators analyzed.

The standard deviation of the general QOL score of 3.8 was used based on a population of 369 people [39], power of $80 \%, 95 \%$ confidence level, $5 \%$ sampling error, and a total of 323 fishermen registered in the studied communities, a sample of 132 artisanal fishermen would be necessary. The sample was increased by $10 \%$ 
for eventual losses related to data collection, and the final sample size was 145 artisanal fishermen.

Descriptive statistic was performed. Additionally, Shapiro-Wilk test was used to analyze the adherence to the normal distribution. When they did not present a normal distribution, logarithmic transformation was performed so that all variables presented normal distribution (Shapiro-Wilk, $\mathrm{p} \geq 0.05$ ) and parametric tests were used. Linear regression models were created. The stepwise backward strategy was used, with variables entry into the model $p=0.20$ and removal $\mathrm{p}=0.05$. Missing were not considered in the analyzes.

Table 1 Socioeconomic demographic characteristics, chronotype, level of physical activity and perceived stress

\begin{tabular}{|c|c|c|}
\hline Variables & $\mathbf{n}$ & $\%$ \\
\hline \multicolumn{3}{|l|}{ Sex } \\
\hline Female & 42 & 29.17 \\
\hline Male & 102 & 70.83 \\
\hline \multicolumn{3}{|l|}{ Daily workload } \\
\hline Up to $12 \mathrm{~h}$ & 47 & 32.64 \\
\hline$>12 \mathrm{~h}$ & 97 & 67.36 \\
\hline \multicolumn{3}{|l|}{ Time of profession } \\
\hline Up to 10 years & 77 & 53.47 \\
\hline$>10$ years & 67 & 46.53 \\
\hline \multicolumn{3}{|c|}{ Number of employment relationship } \\
\hline 1 & 87 & 60.42 \\
\hline$>1$ & 57 & 39.58 \\
\hline \multicolumn{3}{|l|}{ Economic class } \\
\hline A & 4 & 4.00 \\
\hline B & 23 & 23.00 \\
\hline C & 27 & 27.00 \\
\hline D-E & 46 & 46.00 \\
\hline \multicolumn{3}{|l|}{ Smoking } \\
\hline Not & 86 & 60.56 \\
\hline Yes & 56 & 39.44 \\
\hline \multicolumn{3}{|l|}{ Chronotype } \\
\hline Moderately afternoon & 4 & 2.82 \\
\hline Intermediate & 135 & 95.07 \\
\hline Moderately morning & 3 & 2.11 \\
\hline \multicolumn{3}{|l|}{ Physical activity level } \\
\hline Low & 39 & 27.08 \\
\hline Moderate & 49 & 34.02 \\
\hline \multirow[t]{2}{*}{ High } & 56 & 38.90 \\
\hline & Mean & $\begin{array}{l}\text { Standard } \\
\text { deviation }\end{array}$ \\
\hline Age & 50.10 & 8.99 \\
\hline Monthly income (USD) & 427.89 & 386.34 \\
\hline Perceived stress score & 29.07 & 5.11 \\
\hline
\end{tabular}

USD: dollar
The response rate of the variables was less than $20 \%$. The level of significance was $5 \%$ and Stata ${ }^{\circledR}$ (StataCorp, LC) 11.0 was used.

\section{Results}

Of 144 artisanal fishermen studied, the majority were men $(70.83 \%, \mathrm{n}=102)$, worked for more than $12 \mathrm{~h}$ a day $(67.36 \%, n=97)$, worked as artisanal fishers for up to 10 years $(53.47 \% ; n=77)$ and had only one employment relationship (60.42\%; $\mathrm{n}=87$ ) (Table 1 ).

Fishermen with economic class D or E $(46.0 \% ; n=46)$, classified as intermediate chronotype $(95.07 \% ; n=135)$, with high level of physical activity $(38.62 \%$; $n=56)$; and non-smokers $(60.56 \%, \mathrm{n}=86)$ characterized most of the sample. On mean (standard deviation, sd), fishermen presented 50 (8.99) years, monthly income of USD \$ 427.89 (386.34) and perceived stress of 29.07 (5.11) (Table 1).

The mean (sd) of the general QOL perception of artisanal fishermen were 63.98 (18.43) and the QOL satisfaction of 60.41 (26.52), on the scale transformed to 0 to 100 . In relation to the scores of the QOL domains, on mean (sd) artisanal fishermen presented a score of 74.35 (15.29) for social relations, 71.76 (13.39) for the psychological domain, 66, 22 (15.43) for the physical domain and 56.31 (12.22) for the domain environment (Table 2).

The factors associated with each domain of the QOL perception with the general QOL score and with the satisfaction with the fishermen QOL were presented in Table 3.

Sex was associated only with the satisfaction of fishermen with the QOL perception. Based on the male sex, female artisanal fishers had a lower QOL satisfaction score $(\beta=-12.55,95 \% \mathrm{CI}-24.70$ to $-0.39, \mathrm{p}=0.04)$. Age was associated with QOL scores in the physical domains $(\beta=-0.91,95 \% \mathrm{CI}-0.14$ to $-0.04, \mathrm{p}=0.01)$ and social relationships $(\beta=-7.68,95 \% \mathrm{CI}-10.25$ to $-3.60, p=0.01)$, to the general QOL $(\beta=-0.51,95 \%$ $\mathrm{CI}-0.90$ to $-0.01, \mathrm{p}=0.01)$ and satisfaction with QOL $(\beta=-0.69,95 \% \mathrm{CI}-1.29$ to $-0.09, \mathrm{p}=0.02)$. There were only statistically significant differences among

Table 2 Scores of the domains of the WHOQOL-bref

\begin{tabular}{lllll}
\hline Domains & Mean & SD & Min & Max \\
\hline Social relationships & 74.35 & 15.29 & 16.66 & 100 \\
Psychological & 71.76 & 13.39 & 25.00 & 100 \\
Physicist & 66.22 & 15.43 & 17.85 & 100 \\
Environment & 56.31 & 12.22 & 12.50 & 78.1 \\
General quality of life & 63.98 & 18.43 & 0.00 & 100 \\
Overall satisfaction with & 60.41 & 26.52 & 0.00 & 100 \\
$\quad$ quality of life & & & &
\end{tabular}

SD standard deviation, Min minimum value, Max maximum value 
Table 3 Association between socioeconomic demographic characteristics and perception of quality of life

\begin{tabular}{l} 
Domains \\
\hline Physical domain \\
Sex \\
Workload \\
Time of profession \\
Age \\
Economic classification \\
A \\
B \\
C \\
D-E \\
Physical activity level \\
Low \\
Moderate \\
High \\
Perceived stress \\
Psychological domain \\
Sex \\
Workload \\
Economic classification \\
A \\
B \\
C \\
D-E \\
Age \\
Physicalacivity level
\end{tabular}

Physical activity level

Low

Moderate

High

Perceived stress

Social domain

Perceived Stress

Age

Time of profession

Income

Economic class

A
B
D-E

Environment domain

Economic class

A
B
C
D-E

Physical activity level Low

\begin{tabular}{ll} 
Linear regression & \\
\hline$\beta(95 \% \mathrm{Cl})$ & $\mathrm{p}^{*}$
\end{tabular}

$-0.81(-1.83 \cdot 0.21)$

0.12

$-1.00(-1.99 ;-0.01)$

$0.65(-0.24 ; 1.55)$

0.047

$-0.91(-0.14 ;-0.04)$

0.15

0.01

Ref.

$-1.39(-3.74 ; 0.95)$

$-1.97(-4.35 ; 0.39)$

$-2.40(-4.69 ;-0.10)$

Ref.

$0.94(-0.14 ; 2.03)$

$-0.14(-0.24 ;-0.05)$

$-16.32(-31.90 ; 4.68)$

$-28.29(-39.21 ;-8.01)$

Ref.

$-17.11(-45.26 ; 38.24)$

$-12.31(-44.04 ; 40.45)$

$-37.07(-55.67 ; 18.71)$

$-6.06(-8.62 ; 0.77)$

Ref.

$16.55(-23.66 ; 33.29)$

$23.39(-16.55 ; 37.0)$

$-11.83(-14.50 ;-8.36)$

$-13.04(-16.00 ;-9.18)$

$-7.68(-10.25 ;-3.60)$

$26.16(-12.40 ; 39.02)$

$0.25(-0.58 ; 0.46)$

Ref.

$28.90(-39.32 ; 56.71)$

$19.02(-45.67 ; 53.00)$

$-14.10(-51.10 ; 47.05)$

Ref.

$-30.08(-46.91 ; 19.79)$

Ref.

$-32.89(-48.91 ; 15.11)$

0.17

$-37.64(-51.73 ;-12.56)$

0.10

0.03

Ref.
$0.84(-0.26 ; 1.96)$
Table 3 (continued)

\begin{tabular}{|c|c|c|}
\hline \multirow[t]{2}{*}{ Domains } & \multicolumn{2}{|l|}{ Linear regression } \\
\hline & $\beta(95 \% \mathrm{Cl})$ & $\mathrm{p}^{*}$ \\
\hline Moderate & $9.15(-23.35 ; 26.69)$ & 0.79 \\
\hline High & $17.11(-17.51 ; 29.87)$ & 0.33 \\
\hline Perceived stress & $-8.87(-11.42 ;-5.18)$ & 0.01 \\
\hline Number of employment links & $15.17(-17.05 ; 27.41)$ & 0.38 \\
\hline \multicolumn{3}{|l|}{ General quality of life } \\
\hline Income $e^{* *}$ & $3.68(1.29 ; 6.08)$ & 0.01 \\
\hline Perceived stress & $-0.82(-1.54 ;-0.09)$ & 0.03 \\
\hline Time of profession & $5.49(-1.65 ; 12.63)$ & 0.13 \\
\hline Age & $-0.51(-0.90 ;-0.01)$ & 0.01 \\
\hline \multicolumn{3}{|l|}{ Economic classification } \\
\hline$A$ & Ref. & Ref. \\
\hline B & $10.40(-10.02 ; 30.82)$ & 0.32 \\
\hline$C$ & $8.49(-12.50 ; 29.47)$ & 0.42 \\
\hline $\mathrm{D}-\mathrm{E}$ & $-2.28(-23.00 ; 18.41)$ & 0.83 \\
\hline \multicolumn{3}{|l|}{ Satisfaction with quality of life } \\
\hline Sex & $-12.55(-24.70 ;-0.39)$ & 0.04 \\
\hline Age & $-0.69(-1.29 ;-0.09)$ & 0.02 \\
\hline Time of profession & $7.92(-3.02 ; 18.86)$ & 0.15 \\
\hline \multicolumn{3}{|l|}{ Economic class } \\
\hline A & Ref. & Ref. \\
\hline B & $-9.08(-37.85 ; 19.70)$ & 0.53 \\
\hline C & $-11.28(-39.95 ; 17.38)$ & 0.44 \\
\hline $\mathrm{D}$ & $-15.55(-43.50 ; 12.40)$ & 0.27 \\
\hline
\end{tabular}

fishermen belonging to the $\mathrm{D}-\mathrm{E}$ classes when compared to class $\mathrm{A}$ for the physical domains $(\beta=-2.40$, $95 \% \mathrm{CI}-4.69$ to $-0.10, \mathrm{p}=0.04)$ and environment $(\beta=-37.64,95 \% \mathrm{CI}-51.73$ to $-12.56, \mathrm{p}=0.03)$.

The stress perceived was one of the main factors associated to the decrease of QOL in all domains: social relations domains $(\beta=-13.04,95 \%$ CI -16.00 to $-9.18, \mathrm{p}<0.001)$; psychological $(\beta=-11.83,95 \% \mathrm{CI}$ $-14,(\beta=-8.87,95 \%$ CI -11.42 to $-5.18, p=0.01)$; physical $(\beta=-0.14,95 \% \mathrm{CI}-0.24$ to $-0.05, \mathrm{p}=0.01)$ and; in general QOL $(\beta=-0.82,95 \% \mathrm{CI}-1.54$ to $-0.09, \mathrm{p}=0.03)($ Table 3).

Based on the workload of less than $12 \mathrm{~h}$ a day, fishermen working 12 or more hours per day have lower QOL perception in the physical domain $(\beta=-1.00$, $95 \% \mathrm{CI}-1.99$ to $-0.0, \mathrm{p}=0.047)$ and in the psychological domain $(\beta=-28.29,95 \%$ CI -39.21 to -8.01 , $\mathrm{p}=0.03)($ Table 3$)$. 


\section{Discussion}

The factors associated with the QOL perception of artisanal fishermen were female sex, age, economic classification, workload and perception of stress. The main ones' alert to the impact of perceived stress, age and income on the QOL perception.

The findings of this study seem to be the first related to the perception of quality of life Brazilian artisanal fishermen, as well as the factors that may influence this perception. The main ones alert to the impact of perceived stress, age and income on the perception of quality of life. In this sense, the lower income, greater perceived stress and greater age, the lower the quality of life perception scores of artisanal fishermen.

\section{Physical domain}

Age and economic status were factors associated with lower perception of quality of life in the physical domain. The physical domain consists of 12 facets, such as pain and discomfort, energy and fatigue, sleep and rest, and work capacity [40].

The lower socioeconomic status is related to the need for more hours of work and, consequently, greater stress. These factors together with old age are associated with lower scores in the physical domain [40]. Factors together with old age are associated with lower scores in the physical domain [40], therefore older artisanal fishermen had lower scores of perceived QOL [41].

With increasing age, physiological functions and aptitudes and mental abilities trend to decrease. Consequently, the individual's energy decreases [42], impacting on lower energy and higher fatigue scores. Artisanal fishermen with insufficient monthly income must increase productivity for higher income, spend more time fishing, results in increased fatigue and reduced work capacity [15].

Thus, the more time in of profession in fishing, the more likely to arise musculoskeletal disorders to be a profession that involves ergonomic risks related to the management of excess weight, increased exposure to ultraviolet rays that can cause diseases, such as cancer, burns, among others [41, 43]. With these factors there is also increased the dependence on medication or treatments, which have repercussions on the facet pain, discomfort, ability to work.

\section{Psychological domain}

The perceived stress and the workload over $12 \mathrm{~h}$ were the factors associated with lower scores for psychological domain. The increased workload causes mental fatigue and becomes the main source of stress [44, 45]. The consequences of stress in relation to work may be discouragement, anxiety, interpersonal difficulties, lack of interactivity in relation to work activities, fear of the dangers found in the water, among other health problems $[45,46]$, situations that may also impact on the psychological domain.

\section{Social domain}

Age and perceived stress were the factors associated with lower QOL perception in the social domain. This domain consists of facets such as personal relationships, sexual activity, social support, these can be influenced by stress. The lack of support for the profession and policies to encourage small-scale fishing are a reality experienced by these fishermen, especially among older fishermen. In this scenario, fishing activity is weakened, giving rise increase in labor stress and consequent reduction of QOL $[9,47]$.

\section{Environmental domain}

Perceived stress and the socioeconomic level were the factors that reduced the QOL perception in the environmental domain. The artisanal fishermen has as main source of income the fishing and when this is not productive there is decrease of per capita income [48]. Other factors that contribute to fishermen productivity are infrastructure, irritating noises, declining fish species, lack of institutional support and policies aimed at fishing, may lead to deactivation of the activity, and become development of stress [43, 47, 49-51].

The fact that the fishermen stays most of the time in the river for hours or days away from home, in an environment that is precarious hygiene and health care, where there is no physical security and protection, short of the natural adversities of the environment and the fact that this profession is among the most dangerous [17, 43]. This may negatively interfere with the perception of stress [52], as well as the reduction in the related to facet physical security and protection.

\section{Generalisability}

The quantity of artisanal fishermen in the world and the way they preserve their culture and habits, makes this population unique and significant. The state of Tocantins, where the study was conducted, is the newest Brazilian state that is in constant development. Little is known about the life habits, quality of life, chronotype and perceived stress of artisanal fishermen, and the results presented in this study are important for a better understanding and to obtain estimates of these indicators in this vulnerable population. 
The main factors associated with a lower perception of quality of life were related to aspects that can be improved with low cost and easy to implement public policies, such as improving access to sanitary sewage, expanding coverage of health strategy family and the maintenance of income redistribution policies. In general, providing health promotion policies to artisanal fishers aimed at improving income, the perception of quality of life over the age and the reduction of stress can produce positive effects on well-being, consequently in the quality of life score general. Thus, existing public policies and new public policies related to the health of artisanal fishers must consider the specific needs of each region, mainly due to the socioeconomic disparities and inequalities in Brazil.

\section{Limitations}

Several limitations can be related to the study design, sample size and outcome measurement. The study design is the major limitation of this study, since they may influence the external validity of the data and make it impossible to establish a cause and effect. The QOL perception and perceived stress are self-reported and subjective measures, and can limit the extrapolation these data for different fishermen colonies. Additionally, founds of this study should be viewed with caution because of sample size. However, they were obtained from a sample size of the four fishermen colonies, and the full research will include 36 colonies.

\begin{abstract}
Abbreviations
ABEP: Brazilian Association of Research Companies; COPEMITO: Colônia de Pescadores de Miracema do Tocantins; EMBRAPA: Brazilian Company of Agricultural Research-Fishermen and Aquaculture; IPAQ: International Physical Activity Questionnaire; QOL: quality of life; RURALTINS: Rural Development of the State of Tocantins; STROBE: Strengthening the Reporting of Observational Studies in Epidemiology; USD: dollar.
\end{abstract}

\section{Acknowledgements}

Not applicable.

\section{Authors' contributions}

BKRS — wrote all main text of the manuscript. Responsible for communicating with Scientific Reports and managing communication between co-authors. Responsible for ensuring that all authors are included in the list of authors. FWSF-wrote all main text of the manuscript, responsible for statistical analysis. ESM - wrote an introduction and collaborated with the discussion of the manuscript, besides reviewing all writing. FRPQ — responsible for the tables of the manuscript, writing the results and discussion. FA-revised all manuscript writing. All authors read and approved the final manuscript.

\section{Funding}

The research was funded by the EMBRAPA Management System (SEG), program Macro 4, with the number MP4SEG 04.13.09.001.00. The EMBRAPA mediated access to the colonies through the leaders for the research to be presented and subsequently performed data collection. The company also contributed to the transportation of researchers to the colonies and to the materials used for data collection. The funding company did not participate in the construction of this manuscript, only in mediation for data collection.
Availability of data and materials

Not applicable.

\section{Ethics approval and consent to participate}

This research was approved by the Committee for Ethics in Research with Human Beings (CEP) of the Lutheran University Center of Palmas (CEULP/ ULBRA) under the number of the Presentation Certificate for Ethical Assessment (CAAE) 50419215.5.0000.5516. All methods have been performed in accordance with the relevant guidelines and regulations. All participants in the study signed the Informed Consent Term.

\section{Consent for publication}

Not applicable.

\section{Competing interests}

The authors declare that they have no competing interests.

\section{Author details}

1 Epidemiology and Data Analysis Laboratory, Faculdade de Medicina do ABC (FMABC), Santo André, SP, Brazil. ${ }^{2}$ Universidade Federal do Tocantins (UFT)Campus de Miracema, Miracema do Tocantins, Tocantins, Brazil. ${ }^{3}$ Universidade Federal do Tocantins (UFT)-Campus de Palmas, Palmas, Tocantins, Brazil.

Received: 28 February 2019 Accepted: 26 July 2019

Published online: 02 August 2019

\section{References}

1. FAO O das NU para a A e a A (2009) Pesca e Aquicultura - O peixe, fonte de alimentação, meio de subsistência e de comércio. 2.

2. Alves T dos S (2014) Da organização a produção do espaço pesqueiro: a pesca artesanal em Vera Cruz (BA)

3. Ramalho CWN. Sentimento de corporação, cultura do trabalho e conhecimento patrimonial pesqueiro: expressões socioculturais da. Rev Ciências Sociais Fortaleza. 2012;43:8-27.

4. De Sousa DN, Cristina H, Kato DA, Silva C, Milagres F. Perfil socioeconômico e tecnológico dos pescadores de Xambioá, estado de Tocantins Socioeconomic and technological profile of the fishermen of Xambioá Tocantins State. Acta Fish Aquat Resour. 2017:5:113-21.

5. Vieira DM, De Oliveira MA (2016) or Uma Aquicultura Familiar Sustentável : Bases Jurídicas E Da Política Do Setor No. 10:557-567.

6. Andreu-Cazenav M, Dulce Subida M, Fernandez M. Exploitation rates of two benthic resources across management regimes in central Chile: evidence of illegal fishing in artisanal fisheries operating in open access areas. PLOS ONE. 2017;12:1-23.

7. Martínez-Ortiz J, Aires-Da-silva AM, Lennert-Cody CE, Maunderxs MN. The ecuadorian artisanal fishery for large pelagics: species composition and spatio-temporal dynamics. PLoS ONE. 2015;10:1-29.

8. Melli V, Riginella E, Nalon M, Mazzoldi C. From trap to nursery. Mitigating the impact of an artisanal fishery on cuttlefish offspring. PLOS ONE. 2014;1:1. https://doi.org/10.1371/journal.pone.0090542.

9. Mendonça JT, Lucena ACM, Muehlmann LD, Medeiros RP. Socioeconomia da pesca no litoral do estado do Paraná (Brasil) no período de 2005 a 2015. Desenvolv e Meio Ambient. 2017:41:140-57.

10. Jaeschke A, Saldanha MCW. Physical demands during the hauling of fishing nets for artisan fishing using rafts in beach of Ponta Negra, NatalBrasil. Work A J Prev Assess Rehabil. 2012;41:414-21.

11. de Souza SBC, Tavares JP, Macedo ABT, Moreira PW, Lautert L. Influência do turno de trabalho e cronotipo na qualidade de vida dos trabalhadores de enfermagem. Rev Gaúcha Enferm. 2012;33:79-85.

12. Santana CG. As percepções ambientais de pescadores e marisqueiras acerca da divisão sexual de trabalho na pesca em pirambu/se. Ambivalências. 2014;2:86-105.

13. Sousa RGC, Florentino AC, Piñeyro JIG. Inovação de artefatos e caracterização da pesca do camarão Macrobrachium amazonicum (Heller, 1862) na comunidade São Sebastião da Brasília - Parintins/AM. Biota Amaz. 2014;4:83-7.

14. dos Pestana MSV. Saneamento: um indicador de qualidade de vida na comunidade e do entorno da Lagoa do Vigário. Macaé: Instituto Federal de esp Educação, Ciência e Tecnologia Fluminense; 2015. 
15. Trabuco ACSR (2015) Doenças relacionadas ao trabalho em marisqueiras e pescadores artesanais.

16. Chinnakali P, Thekkur P, Manoj Kumar A, Ramaswamy G, Bharadwaj B, Roy G. Alarmingly high level of alcohol use among fishermen: a community based survey from a coastal area of south India. J Forensic Leg Med. 2016;42:41-4.

17. de Oliveira CM, de Viana GS, dos Santos TC, da Mota DS, da Costa MJSM Ximenes Neto FRG. Dores e delícias da pesca artesanal: um olhar para a influência do meio ambiente no trabalho e na saúde. Ensino Saude e Ambiente Backup. 2017;10:187-202.

18. Kilpatrick S, King TJ, Willis K. Not just a fisherman's wife: women's contribution to health and wellbeing in commercial fishing. Aust J Rural Health. 2015:23:62-6.

19. Neves-Silva $P$, Heller $L$. The right to water and sanitation as a tool for health promotion of vulnerable groups. Cien Saude Colet. 2016:21:1861-70.

20. Remmen LN, Herttua K, Riss-jepsen J, Berg-beckhoff G. Fatigue and workload among Danish fishermen line. Int Marit Heal. 2017;68:252-9.

21. Coimbra CEA Jr, Santos RV. Saúde, minorias e desigualdade: algumas teias de inter-relações, com ênfase nos povos indígenas no Brasil Health, minorities and inequality: some webs of inter-relations, emphasizing indigenous peoples in Brazil. Cien Saude Colet. 2000;5:125-32.

22. von Elm E, Altman DG, Egger M, Pocock SJ, Gøtzsche PC, Vandenbroucke JP. The strengthening the reporting of observational studies in epidemiology (STROBE) statement: guidelines for reporting observational studies. Int J Surg. 2014;12:1495-9.

23. de Carvalho EV, Batista AC, Coelho MCB, Neves COM, dos Santos GR, Giongo M. Characterization of wildfires in Tocantins State on 2014 season. Floresta. 2017:47:269-78.

24. Aguiar $\vee$ dos S (2015) A extração de areia no Rio Tocantins em Imperatriz-MA: dinâmica econômica e socioambiental na perspectiva de empoderamento.

25. $A B E P A B$ de E de $P$ (2016) Critério de Classificação Econômica Brasil CCEB. Códigos e guias 1-6.

26. Cohen S, Kamarck T, Mermelstein R. A global measure of perceived stress a global measure of perceived stress. J Health Soc Behav. 1983;24:385-96.

27. Reis RS. Comportamentos de risco à saúde e percepção de estresse em professores universitários das IFES do sul do brasil. Programa PósGraduação em Eng. Produção Tese de do. 2005.

28. Cohen S, Tyrrell DA, Smith AP. Negative life events, perceived stress, negative affect, and susceptibility to the common cold. J Pers Soc Psychol. 1993;64:131-40.

29. Xavier KGDS, Vaghetti HH. Aspectos cronobiológicos do sono de enfermeiras de um hospital universitário. Rev Bras Enferm. 2012;65:135-40.

30. Roenneberg T. What is chronotype? Sleep Biol Rhythms. 2012;10:75-6.

31. Wills TA, Cohen S. Ovid: stress, Social Support, and the Buffering Hypothesis. Psychol Bull. 1985;98:310-57.

32. da Silva RM, Zeitoune RCG, Beck CLC, De Martino MMF, Prestes FC, Loro MM. Cronotipo e turno de trabalho em trabalhadores de enfermagem de hospitais universitários. Rev Bras Enferm. 2017:5:1009-15.

33. Matsudo S, Araújo T, Matsudo V, Andrade D, Andrade E, Oliveira LC, Braggion G. Questionário Internacional De Atividade Física (Ipaq): estupo De Validade E Reprodutibilidade No Brasil. Rev Bras Atividade Física Saúde. 2001;6:5-18.

34. Matsudo SM, Matsudo VR, Araújo T, Andrade D, Andrade E, Oliveira L. Nível de atividade física da população do Estado de São Paulo: análise de acordo com o gênero, idade, nível socioeconômico, distribuição geográfica e de conhecimento. Rev Bras Ciência e Mov. 2002;10:2002.
35. Who WHO. The world health organization. Const World Health Organ. 1946;2:428-30.

36. Fleck MPDA. O instrumento de avaliação de qualidade de vida da Organização Mundial da Saúde (WHOQOL-100): características e perspectivas. Cien Saude Colet. 2000;5:33-8.

37. Whoqol Group. The World Health Organization Quality of Life assessment (WHOQOL): position paper from the World Health Organization. Soc Sci Med. 1946;41:1403-9.

38. Maciel MED, de Oliveira FN. Qualidade de vida do profissional técnico de enfermagem: a realidade de um hospital filantrópico em DouradosMS. Rev Psicol e Saúde. 2014;6:83-9.

39. Silva BKR, Quaresma FRP, da Maciel ES, dos Figueiredo FWS, Sarraf JS, Adami F. Correlation between stress and quality of life experienced by caregivers: perception of a group of healthcare professionals. Open Nurs J. 2017;11:135-41.

40. Maia TMT, Matos MLS, Silva MHS, Vargas MM, Melo CM. Avaliação da função sexual de mulheres de 40-60 anos cadastradas em unidades de referência no município de Aracaju/Se. Congr Int Enferm. 2017;1:1-5.

41. Müller J, Santos Falcão IR, Couto MCBM, da Viana WS, Alves IB, Viola DN, Wods CG, Rêgo RF. Health-related quality of life among artisanal fisherwomen/shellfish gatherers: lower than the general population. Int J Environ Res Public Health. 2016;13:1-12.

42. Barreto J. Envelhecimento e qualidade de vida: o desafio atual. Sociol Rev da Fac Let da Univ do Porto. 2017;15:289-302.

43. Borges LR, de Silva TAE, Batrista LX. Fatores De Riscos Ambientais Presentes Na Pesca Artesanal De Valença- Bahia. Revis Bras de Engenharia de Pesca. 2016;9:37-44.

44. Santos LSC, de Guirardello EB. Nurses' attention demands in the work setting. Rev Lat Am Enfermagem. 2007;15:27-33.

45. Paschoal T, Torres CV, Porto JB. Felicidade no Trab balho: R relações com sup porte o rganizac cional e suporte social. Revista Adm Contemp. 2010;14:1054-72.

46. Dalri RDCDM, da Silva LA, Mendes AMOC, do Robazzi MLCC. Nurses' workload and its relation with physiological stress reactions. Rev Lat Am Enfermagem. 2014;22:959-65.

47. Miranda EB, Ferreira DTAM, Marques EE. Dos conflitos à invisibilização da pesca profissional do Estado do Tocantins. Rev Gestão Sustentabilidade Ambient. 2017:6:272-98.

48. Pessoa Neto WA, de Brasil MVO, do Melo AN, De Moura EA. Sistema de relações de produtores de tilápia à luz da teoria visionária de filion. CONNEXIO. 2017:6:11-31.

49. Silva BKR, Zica M, Barbosa T, Quaresma F, Sonati J, da Maciel ES. Percepção da qualidade de vida, estresse, nível de atividade física e cronotipo em grupo de enfermeiros das unidades de pronto atendimento do Brasil. Rev da UIIPS. 2016;4:103-13.

50. Rabelo YGS, de Vaz EM, Zacardi DM. Perfil socioeconômico dos pescadores artesanais de dois lagos periurbanos de Santarém. Estado do Pará: Rev Desafios; 2017. https://doi.org/10.20873/uft.2359-3462.2017v4n3p73.

51. Zacardi DM, Saraiva ML, de Vaz EM. Caracterização da pesca artesanal praticada nos lagos Mapiri e Papucu às margens do rio Tapajós, Santarém, Pará. Rev Bras Eng Pesca. 2017;10:31-43.

52. Pollnac RB, Poggie JJ. Happiness, well-being and psychocultural adaptation to the stresses associated with marine fishing. Hum Ecol Rev. 2008;15:194-200.

\section{Publisher's Note}

Springer Nature remains neutral with regard to jurisdictional claims in published maps and institutional affiliations. 